\title{
The Influence of Intellectual Capital on Competitive Advantage on Universities in Medan City
}

\author{
Isfenti Sadalia \\ Department of Management \\ Faculty of Economics and Business \\ Universitas Sumatera Utara \\ Medan, Indonesia \\ isfentisadalia@gmail.com
}

\author{
Nisrul Irawati \\ Department of Management \\ Faculty of Economics and Business \\ Universitas Sumatera Utara \\ Medan, Indonesia \\ nisrulirawati@yahoo.com
}

\author{
Isdiana Syafitri \\ Kopertis
}

\begin{abstract}
The purpose of this research is to analyze the influence of intellectual capital on competitive advantage. The samples of this research is 80 (eighty) lecturers in several universities in Sumatera Utara province, by applying simple random sampling. Data was analyzed by using multiple linier regression analysis. Result showed that human capital does not have significant influence on competitive advantage, while both the structural capital and relational capital have positive and significant influence on competitive advantage.Simultaneously intellectual capital has significant influence on competitive advantage. Lastly, intellectual capital can influence competitive advantage is about $37 \%$.
\end{abstract}

Keywords; intellectual capital, competitive advantage, lecturer, university

\section{INTRODUCTION}

Universities are institutions of higher education and research which award academic degrees in various academic disciplines. These disciplines are hoped to develop the students into a more competent future generation. To achieve this more competent and competitive next generation, there is an obvious need for competent lecturers. This requirement is because of universities are not exempt from competition. [1]

The competitiveness of the academia is not only applied to the physical institution but also the human resources behind it (in this case, the college's lecturers). A college or institution would enjoy more reputation and respectability if it holds a commendable staff and human resources. One of the efforts to increase the quality of the teaching human resources is to increase their knowledge base. Prahalad and Hamel (1990) said that by combining resources and knowledge in ways that provide access to multiple, unique, sustainable market opportunities, a firm can create and maintain a core competency. [2]

Because physical and financial assets no longer the primaries to facilitate competitive edge in a knowledge based society, knowledge itself becomes the only mean for competitive advantage. (Kaplan and Norton, 2001; Kong and Prior, 2008). [3]
Competitive advantage is a position where a company has cornered it's own business market. (Porter, 1998). Thecompany has been able to differentiate itself and moved on ahead the competition, In the current global competitive environment, there is a need for the capability to initiate a fast and concise dynamic response dan for a flexible organizational goals from maximizing profits to maximizing value. (Freeman, 2001). [4]

According to Handoko (2002) a hard to imitate and long lasting competitive edge is human resource through practices of human resources within the company. Human resources witjin a company can be assessed by intellectual capital. While Zimmerer and Scarborough (2005: yi) states yhat intellectual capital is the key to competitive advantagr which consists of ;(1) human capital, (2) structural capital dan (3) customer capital. Customer capital can also be called relational capital. [5]

Based on that background, researchers are interested observe the effect of intellectual capital to competitive advantage. [6]

\section{LITERATURE REVIEW}

\section{A. Competitive Advantage}

Zimmerer and Scarborough (2005: 69) said that competitive advantage is the aggregation of factors that sets a small business apart from its competitors and gives it a unique position in the market superior to its competition. To gain competitive advantage over its rivals, a company must either perform these activities at a lower cost or perform them in a way that leads to differentiation and a premium price (more value). [7]

Barney (1991) specifically noted that competitive advantage can be achieved if the firm implements a valuecreating strategy that is not simultaneously being implemented by any current or potential competitors. [8]

\section{B. Intellectual Capital}

Intellectual Capital is an intangible asset owned by a company. According to Lonnquist and Mettanen (2003), intellectual capital has these kinds of characteristics; (1) invisible, (2) highly related to the knowledge and experience of the employees, also the technological base of the 
organization and (3) gives an opportunity for the organization to succeed in the future. [9]

Sofian et al. (2008) describe intellectual capital as the possession of knowledge and experience, professional knowledge and skill, goal relationships, and technological capacities, which when applied can give organizations competitive advantage. [10]

Based on Meritum (2002) who adopted the intellectual capital methodology from Sveiby (1997) expands intellectual capital into three categories; human capital, structural capital and relational capital. [11]

Human capital can be defined as a key element in increasing a company's assets and employees to increase productivity as a support for competitive advantage (Schultz, 1993). Meanwhile Roos et al. (1997) and McGregor et al. (2004) defines human capital as a composition of values, attitudes, qualifications and skills of employees who contributes to the value of an organization. From that definition, it can be concluded that human capital are aptitudes from the human resources of a company that increases the value of said company. Human includes various human resource elements, including attitude, competencies, experience and skills, tacit knowledge and the innovativeness and talents of people (Choo and Bontis, 2002). [12]

Structural capital is what happens among the people, how the people are connected within the company, and what stays when the employee leaves the company (Halim, 2010). While Roos et al. (1997) states that structural capital is what remains in the company when employees go home for the night.Structural capital is defined as non human company assets that supports the individuals within for the benefit the company's activities. Structural capital includes all of the nonhuman storehouses of knowledge in organizations such as databases, process manuals, strategies, routines, organizational culture, publications and copyrights which creates value for organization, thus adding to the organization' material value (Bontis et al., 2000). While Halim (2010) also assume structural capital is a stock of knowledge that is owned by the firm and includes corporate culture, information technology and explicit knowledge, product innovation, process optimization, and innovation among others. [13]

Welbourne (2008) defined relational capital as an intangible asset that is based on developing, maintaining and nurturing high- quality relationships with any organization, individuals or group that influences or impacts your business. Jardon and Martos (2012) states thatrelational capital is based upon the development, maintenance and upkeep on a high level of internal relationships within the company, personal or groups, that has an impact on the business of the company. Relational capital is also how organizations communicate with other parties that influences their activities. RC is the flow of knowledge from an organization to the external environment. This includes reputation and influence over the distribution channel, suppliers, clients as well as governments and industry associations (Grasenick and Low, 2004). [14]

\section{Conceptual Framework}

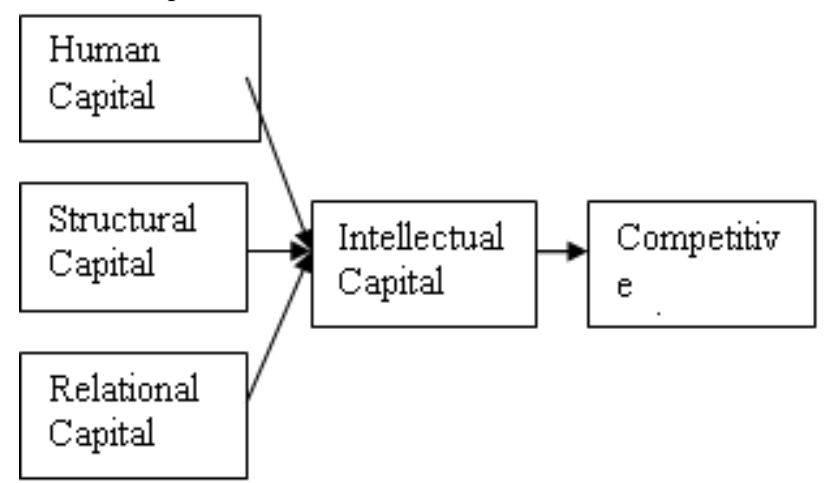

Figure 1. Conceptual Framework

\section{Hypotesis}

According to Hsu and Fang (2008) a high quality employee is important to a economic company. Pfeffer (1994) noted thar, how a company retains and trains their human resources is an important strategy, in a knowledge based context.A conclusion can be drawn, that the higher the knowledge base of the employees (human resources), the more better the competitive advantage can be achieved by an organization. [15]

H1: Human capital directly influences competitive advantage.

Lopez et al. (2006) states that organizational knowledge is a source for a sustainable competitive advantage. This indicates an increase of structural capital will improve the competitive advantage value.

\section{H2: Structural capital influences competitive advantage}

Because relational capital has the potential to shape competitive advantage for a company, through the molding of a unique competent core, in the form of relationships embedded in organizational network.(Subramaniam dan Youdt, 2005).

H3: Relational capital influences competitive advantage

\section{METHOD}

The research was conducted on four colleges in North Sumatra, during May to June, 2017. The research object were lecturers on those colleges..

The data used were primary data that were collected through questionnaires dispersed to the lecturers that were the research respondents. The survey data were measured by the Likert Scale, with the score 1 as strongly disagree to 5 as strongly agree. The questionnaire were 100 questions spread to 100 respondents, out of the one hundred respondents only 80 participated. The sample selection technique used is random sampling.

The data analysis process used was descriptive analysis and linear regression analysis. Descriptive analysis was used to give an image and information about the data variables. Multiple linear regression analysis was used to determine the interaction between free and constrained variables. 


\section{RESULT}

\section{A. Characteristic of Respondents}

From this research, it is known the result of descriptive analysis for characteristic of respondents from this research's sample. Characteristic of respondents from this research can be seen from Table 1 below.

\section{TABLE 1. CHARACTERISTIC OF RESPONDENTS}

\begin{tabular}{|c|c|c|c|}
\hline No & Characteristic & Total & Persentage \\
\hline 1. & \begin{tabular}{ll}
\multicolumn{2}{l}{ Genre } \\
- & Male \\
- & Female
\end{tabular} & $\begin{array}{l}46 \\
34\end{array}$ & $\begin{array}{l}57.5 \% \\
42.5 \%\end{array}$ \\
\hline 2. & $\begin{array}{cl}\text { Age } & \\
- & 20-40 \text { years old } \\
- & 41-60 \text { years old } \\
- & >60 \text { years old }\end{array}$ & $\begin{array}{r}41 \\
36 \\
3\end{array}$ & $\begin{array}{r}51.3 \% \\
55.1 \% \\
3.8 \%\end{array}$ \\
\hline 3. & \begin{tabular}{ll}
\multicolumn{2}{l}{ Education } \\
- & S1 (Bachelor degree) \\
- & S2 (Master Degree) \\
- & S3 (Doctorate Degree) \\
Experience as lecturer \\
$-\quad 1-14$ years \\
$-\quad 15-28$ years \\
$-\quad>29$ years
\end{tabular} & $\begin{array}{r}4 \\
70 \\
6 \\
49 \\
26 \\
5\end{array}$ & $\begin{array}{r}5.0 \% \\
87.5 \% \\
7.5 \% \\
61.3 \% \\
32.6 \% \\
6.3 \%\end{array}$ \\
\hline
\end{tabular}

From Table 1 it can be seen the characteristic of respondents in this research. From all of sample, male respondents are 46 people $(57,5 \%)$. While female respondents only 34 people $(42,5 \%)$. It is explain that majority respondents of this research are male lecturer, who participate to fulfill the questioner.

According to age, from 20 year old until 40 years old respondents as many as 41 lecturers $(51,3 \%)$, age from 40 years old until 60 years old as many as 36 lecturers $(55,1 \%)$, and the older than 60 years old as many as 3 lecturers $(3,8 \%)$. It is indicate that majority lecturers in this research had been 41 years old until 60 years old.

According to education rate of the respondents, respondents with education until bachelor degree is as many as 4 lecturers (5\%), master degree as many as 70 lecturers $(87.5 \%)$ and the last doctorate degree 6 lecturers $(7,5 \%)$. It is indicated that majority lecturers in universities in Medan city have level of education in master degree. It is caused many of universities more like recruiting prospective lecturers who have level of education in master degree. And many of lecturers not yet continue their study to doctorate degree, or still in the progress to get doctorate degree.

Lastly, according to the length of the respondents' tenure, respondents who worked from between 1 to 14 years were 49 people $(61.3 \%)$, respondents who worked between 15 to 28 years were 26 people $(32.6 \%)$ and finally respondents who worked for more than 29 years were 5 people $(6.3 \%)$.

From the results from the multiple linear regression analysis research done, revealed the interaction between free and constrained variables that shown in Table II below:
TABLE 2. REGRESSION ANALYSIS

\begin{tabular}{|c|r|r|}
\hline Model & Coefficient & Signifikan \\
\hline Konstanta & 4.004 & 0.363 \\
\hline Human capital $\left(\mathrm{X}_{1}\right)$ & 0.068 & 0.476 \\
\hline Structural capital $\left(\mathrm{X}_{2}\right)$ & 0.341 & 0.000 \\
\hline Relational capital $\left(\mathrm{X}_{3}\right)$ & 0.213 & 0.038 \\
\hline & & \\
\hline Regression (Uji-F) & & 0.000 \\
\hline Adjusted R Square & 0.370 & \\
\hline
\end{tabular}

Source: processing data (2017)

According to the regression analysis from Table II, there can be observed constant value of 4,004. This explains that without considering free variables, the value of competitive advantage is 4,004 .

According to the human capital, can be observed a coefficient value of 0.068 and significance value of 0.476 . This shows that human capital had a positive influence but not significant to competitive advantage. The value of human capital of lecturers that taught in colleges in Medan, has no influence on the competitive advantage of their respective colleges. In other words, human capital has no influence on the competitive advantage of colleges in Medan.

The result of this research is different from Campbell et al (2012) dan Taie (2014) that states that human capital has a significant positive impact on competitive advantage.

Structural capital has coefficient value of 0.341 and significance value of 0.000 . This would mean that structural capital has significant positive influence on competitive advantage. The increase in structural capital will improve the competitive advantage. This is because of structural capital's importance to the continuity of an organization, a good structural capital will provide convenience and comfort to its working individuals. That comfort and convenience in turn will increase productivity of the individuals and would make their working colleges competitive advantage. This result concurs with the research done by Taie (2014) that discovered significant positive influence of structural capital on competitive advantage.According

Relational capital has a coefficient value of 0.213 and significance value of 0.038 . This means that relational capital has significant positive influence on competitive advantage. The increase of of relational capital would increase competitive advantage of colleges. Relational capital is the knowledge that is embedded in the relationships of customers, providers, industrial associations or other interested parties that influences the continuity of an organization. The lecturers' good relationship with the students, colleagues and the community would improve the college's public image. This would also mean a positive feedback to the college. From the college lecturers in Medan it has been revealed that they nurture a good relationship with their students, colleagues, the staff and the community. These results is in concurrence with 
the result from Taie (2014) yang which shows the significant positive influence on competitive advantage.

From these simultaneous test result, put together human capital, structural capital, relational capital has a significance value of 0.000 . This means in unison these capitals has an influence on competitive advantage, in other words intellectual capital has an in influence in competitive advantage. This is because as an individual's (employee)knowledge improves, so will they also have competitive performance to compete with other individuals, that will improve the organization's competitive advantage.

Based on coefficient determination test, it has been revealed that adjusted $r$ square value 0,370 . This translates as intellectual capital is capable of influencing competitive advantage as much as $37,0 \%$. The rest, $63 \%$, are influence by other factors that is not covered in this research.

\section{CONCLUSION}

From the research done to 80 lecturers that taught in various colleges in Medan, to observe the interaction between intellectual capital and competitive advantage, these results are observed:

1. Human capital has a insignificant positive influence on competitive advantage.

2. Structural capital has a significant positive influence on competitive advantage.

3. Relational capital has an significant positive influence on competitive advantage.

4. Simultaneously intellectual capital (human capital, structural capital dan relational capital) has a significant positive influence on competitive advantage.

5. human capital, structural capital dan relational capital has a $37 \%$ influence on competitive advantage.

For the college lecturers, while having a good knowledge base, it is also better to keep improving intellectual capital. Not just personal knowledge, but also relationship with internal and external environments needs to be nurtured for improving competitive advantage.

For the researchers, it is advised to improve the range of the sample to achieve a more accurate result. It is also better to add in more variables that influences competitive advantage.

\section{REFERENCES}

1. Zimmerer, Thomas W. dan Norman M. Scarborough. 2005. Essentials of Entrepreneurship and small business management, fourth edition. Malaysia. Pearson Prentice Hall.

2. Taie, Eman Salman. 2014. The effect of intellectual capital management on organizational competitive advantage in Egyptian hospitals. International Journal of Business and Social Science 5(2) : 160-167.

3. Choo CW, Bontis N. (eds). 2002. The Strategic Management of Intellectual Capital and Organisational Knowledge. Oxford University Press: Oxford.

4. Bontis N, Keow WCC, Richardson S. 2000. Intellectual capital and business performance in Malaysian industries. Journal of Intellectual Capital 1(1): 85-100.
5. Grasenick K, Low J. 2004. Shaken, not stirred: defining and connecting indicators for the measurement and valuation of intangibles. Journal of Intellectual Capital 5(2): 268-281.

6. Barney, J. (1991), "Firm resources and sustained competitive advantage", Journal of Management, Vol. 17 No. 1, pp. 99-120.

7. Halim, S. (2010), "Statistical analysis on the intellectual capital statement", Journal of Intellectual Capital, Vol. 11 No. 1, pp. 61-73.

8. Prahalad, C.K. and Hamel, G. 1990, "The core competence of the corporation", Harvard Business Review, Vol. 68 No. 3, pp. 79-91.

9. Welbourne, T.M. (2008), "Relational capital: strategic advantage for small and medium-sized enterprises (SMEs) through negotiation and collaboration", Journal of Business and Economics, Vol. 18 No. 5, pp. 438-92.

10. Pfeffer, J. (1994), Competitive Advantage through People: Unleashing the Power of the Workforce, Boston: Harvard Business School Press.

11. Kaplan RS, Norton DP. 2001. The Strategy-Focused Organisation: How Balanced Scorecard Companies Thrive in the New Business Environment. Harvard Business School Press: Boston, Massachusetts.

12. Sveiby, K. 1997, The New Organizational Wealth: Managing and Measuring Knowledge-based Assets, Berrett-Koehler Publishers, San Francisco, CA.

13. Sofian, S., Tayles, M.E. and Pike, R.H. 2008, "Intellectual capital: an evolutionary change in management accounting practices", Working Paper Series No. 04/29, Bradford University School of Management, Bradford.

14. Roos, J., Roos, G., Dragonetti, N. and Edvinsson, L. 1997, Intellectual Capital: Navigating in the New Business Landscape, New York University Press, New York, NY.

15. Campbell, Benjamin, A. Russell Coff and David Kryseynski. 2012. Rethinking Sustained Competitive Advantage from Human Capital. Academic of Management Review, Vol. 37, No.3, pp. 376-395.

16. Kong, Eric and Daniel Prior. 2008. An Intellectual capital persfective of competitive advantage on nonprofit organisation. International Journal of Nonprofit and Voluntary Sector Marketing, pp.119-128.

17. Schultz, Theodore W. 1993. The Economic Importance of Human Capital in Modernization. Education Economics, Vol.1, No.1, pp. 13-19.

18. Jardon, Carlos M and Maria Susana Martos. 2012. Intellectual capital as competitive advantage in emerging cluster in Latin America. Journal of Intellectual Capital, Vol.13, No.4, pp.462-481.

19. Subramaniam Mohan and Mark A. Youndt. 2005. The influence of intellectual capital on the types of innovative capabilities. Academy of Management Journal, Vol.48, No.3, pp.450-463.

20. Porter, Michael E. 1998. Strategi Bersaing Alih Bahasa Sigit Suryanto. Jakarta: Karisma Publishing Group. 